Anna TURLEJ, Marta SKOLNIAK, Bolesław GIEMZA

Air Force Institute of Technology (Instytut Techniczny Wojsk Lotniczych)

\title{
EVALUATION OF THE IMPACT OF GLYCOL ANTIFREEZE ON THE SURFACES OF TYPICAL CONSTRUCTION MATERIALS OF HEAT EXCHANGERS
}

\section{Ocena wpływu glikolowych płynów chłodzących na powierzchnie typowych materiałów konstrukcyjnych wymienników ciepła}

\begin{abstract}
Glycol-based antifreeze liquids are used in two main areas: ICECS and HVAC. The standard research methods and requirements were developed to control the quality of fluids for the internal combustion engine cooling systems. Irrespective of the intended use, fluid tests are conducted with the same methods. This manuscript aims to study two types of antifreeze with standard methods. Then, the analysis was deepened to include microscopic techniques to identify the potential pitting corrosion centres on the surface of the selected metals. It was demonstrated that the application of microscopic techniques could significantly increase the chance to detect potential corrosion centres.
\end{abstract}

Keywords: corrosion pits, infrastructure heating systems, HVAC systems, studies of glycol antifreeze liquids

Streszczenie: Plyny niskokrzepnace na bazie glikoli sa wykorzystywane w dwóch głównych obszarach: ICECS oraz HVAC. Znormalizowane metody badań oraz wymagania zostaty opracowane w celu kontroli jakości płynów do układów chłodzenia silników spalinowych. W przypadku systemów HVAC inne sa warunki i czas eksploatacji plynów niż w układach chłodzenia silników, nie ma jednak odrębnie zdefiniowanych wymagań i metod badań dla tych płynów. W niniejszej pracy zbadano dwa rodzaje płynów niskokrzepnacych metodami znormalizowanymi, a następnie pogtębiono analize poprzez zastosowanie technik mikroskopowych do identyfikacji potencjalnych ognisk wżerów korozyjnych na powierzchniach wybranych metali. Wykazano, że zastosowanie technik mikroskopowych może istotnie zwiększać szanse na wykrycie potencjalnych ognisk korozji.

Słowa kluczowe: wżery korozyjne, infrastrukturalne systemy grzania, chłodzenia i wentylacji, systemy HVAC, badania glikolowych płynów niskokrzepnących 


\section{Introduction and the aim of the paper}

In metal structures, where the working medium is glycol-based fluid, the dominant process that degrades metal elements is electrochemical corrosion. The metals in contact with each other from which individual elements are made differ in the value of electrochemical potentials and form a cell in which the glycol working medium plays the role of an electrolyte $[7,8]$. Oxidizing processes take place on the surface of the metal with the lower electrochemical potential. The anode collects electrons and causes positive ions to move to the electrolyte solution. In the cathode region occur many complex reduction processes, and their final effect depends on the type of materials that form a cell as well as the chemical composition of the electrolyte.

The standards that define estimation methods of the corrosive effect of glycol-based fluids [6] and requirements in this field [5] were developed to study the fluids intended for internal combustion engine cooling systems (ICECS). The operational practice shows that the working life of the heating, ventilation and air conditioning (HVAC) is much longer in comparison to the working life of internal combustion engines. Due to the extended service life, the exposure of construction materials to the aggressive glycol working medium is much longer as compared to infrastructure systems.

Standard corrosion test provides a certain simulation that accelerates the processes, which occur gradually in the real operating conditions of the internal combustion engine cooling system. Corrosion damage caused by antifreeze liquids used in internal combustion engine cooling systems is assessed by a gravimetric method. The presence of corrosion pitting is investigated in a macro-scale visual inspection.

It is widely accepted that irrespective of the intended use of the liquid, tests are done with the same methods. Standard test methods for determining corrosion damage with a gravimetric method and visual inspection on a macro-scale enable us to estimate corrosion risk associated with the shorter operation of ICECS. However, it can be assumed that under simulated test conditions, micro-changes occur on the surfaces of metal test plates. They do not have to exert a significant impact in the case of the shorter service life of ICECS, but they can indicate corrosion risk to HVAC systems under long-term operation. In this context, the gravimetric analysis combined with the assessment of corrosion pitting conducted only on a macro-scale might not provide us with sufficient information on the risk of corrosion in HVAC systems.

This paper aimed to study whether the corrosion risk assessment with a standard method for antifreeze liquids used in ICECS can be a valid and sufficient way to determine the corrosive effect of these liquids when they are the working agents in the infrastructure heat exchangers. Two types of antifreeze liquids with different composition were examined. The structures formed under their influence on the surfaces of two selected types of metals, included in the group of basic construction materials used in the construction of infrastructure heat exchangers, were identified and compared. 


\section{Methodology and research process}

Two antifreeze liquids based on ethylene glycol containing different corrosion inhibitor packets were investigated in this research. Sample 1 contained corrosion inhibitor packet with inorganic additives (applied in liquids intended for old types of vehicles). The formula of the second sample was based on the newer technology of organic additives [1-4].

The test consisting in touching the "cube" made of six metals joined into a cell with the tested fluid at an elevated temperature was performed according to the executive standard [6]. In these tests, construction material grades were applied that are used in standard corrosion tests of antifreeze for internal combustion engine cooling systems. The test was carried out at a temperature of $86-90^{\circ} \mathrm{C}$ for 336 hours without any interruption. During the test, the airflow of $90-110 \mathrm{~cm}^{3} / \mathrm{min}$ was passed through the tested fluid.

As part of the assessment, the gravimetric analysis was performed. It was based on determining the difference in plate weight after the test relative to its weight before the test. The change in the weight of test plates was estimated on the basis of criteria provided in the standard for antifreeze liquids intended for internal combustion engine cooling systems. Based on the document [6] it was assumed that by the change in the weight of the copper plate by more than $10 \mathrm{mg}$ and aluminium plate by more than $30 \mathrm{mg}$, the effect of the antifreeze should be considered corrosive.

Visual inspection was used to identify corrosion pitting. Visual macroscopic inspection of the plate surface was done in a lightbox with the use of macro photography taken with the Nikon D7200 camera equipped with the Nikkor AF-S Micro Nikkor 105 lens. The microscopic examination was performed with the use of the Nikon LV100ND furnished with a Nikon DS-Ri2 digital camera and NIS BR software. The following EPI observation techniques (using reflected light) were applied:

- bright field - BF,

- fluorescence - FLUO 1 (UV-2A filter), FLUO 2 (GFP-B filter),

- Nomarski Differential Interference Contrast - DIC.

Bright field technique enables to identify objects with different reflecting and diffusive power of the light beam incident perpendicular to the tested sample surface. Objects of different colours, non-transparent, and with clear contours, are clearly visible. One can also observe deformations (roughness, cavities) on the tested sample surface that will become darker by scattering part of the light beam. This technique allows us to identify potential objects such as coatings, sediments, precipitates, discolorations and pits.

Fluorescence technique (FLUO) is the spectro-chemical analysis method in which the molecules of the analyte are excited by irradiation. It uses the displacement of the emission band towards longer wavelengths relative to the absorption band. In the tests, the following fluorescence filters were applied:

- FLUO 1 (UV-2A filter) - excitation band 330-380 nm, emission band $>420 \mathrm{~nm}$,

- FLUO 2 (GFP-B filter) - excitation band 450-490 nm, emission band $510-560 \mathrm{~nm}$. 
It also enabled to observe BF transparent layers on the surface of tested plates.

Nomarski interference contrast (DIC) is an optical microscopy technique, which, by using polarized light and a special structure of Wolston-Nomarski prism enabled to obtain a quasi-spatial image of the test plates surface. It allows for better visualization of the topography of the tested surfaces - thickness of the potential layers or depth of pits.

\section{Results}

The structure of the typical heat exchanger applied in HVAC systems, where glycol solution is used as a working medium, usually consists of copper coil pipe mounted in an aluminium frame. Therefore, these two types of materials were investigated in the presented research in the first place.

The average change in plate weight was estimated based on the measurements of plates that come from three identical test sets described in point 2 . The average values of change in weight of plates immersed in a liquid comprising inorganic and organic additives, respectively, is illustrated in table 1 .

Table 1

The average change in weight (in $\mathbf{m g}$ ) of metal plates after 336 hours of exposure to antifreeze solution at a temperature of $86-90^{\circ} \mathrm{C}$, with the airflow of $90-110 \mathrm{ml} / \mathrm{min}$. The average value was computed based on the results collected from 3 plates. Result for aluminium before and after etching in the nitric acid solution

\begin{tabular}{|l|l|l|}
\hline Sample & $\begin{array}{l}\text { The average change in weight of } \\
\text { plates immersed in a sample } \\
\text { comprising inorganic additives } \\
{[\mathrm{mg}]}\end{array}$ & $\begin{array}{l}\text { The average change in weight of } \\
\text { plates immersed in a sample } \\
\text { comprising organic additives } \\
{[\mathrm{mg}]}\end{array}$ \\
\hline $\mathrm{Cu}$ & -0.1 & -0.1 \\
\hline $\mathrm{Al}$ & $+29.0 /+0.7$ & $+3.6 /-2.3$ \\
\hline
\end{tabular}

The high average increase in weight was observed in aluminium plates, which formed a cell element reacting with the solution of the liquid containing inorganic additives. The average increase in weight of aluminium plate immersed in a liquid containing organic additives was approximately eight times lower as compared to the plate exposed to the liquid with inorganic additives.

When a thick deposit is formed on test plates, the standard recommends removing it by cleaning with a soft bristle brush and immersing in the nitric acid solution with the concentration of approx. $12 \mathrm{~mol} / \mathrm{dm}^{3}$ for 10 minutes in room temperature. Then, it should be cleaned in the distilled water and air-dried [6]. The treatment was conducted to remove the deposited barrier formed on aluminium plates immersed in a liquid containing inorganic additives, which significantly inhibited microscopic visualization of potential corrosive 
changes. After that, measurement of the weight was once again taken. Also, change in the weight was compared to the weight before the test.

The examples of test plate surfaces obtained due to the macroscopic visual inspection were exhibited in fig. 1.

a)

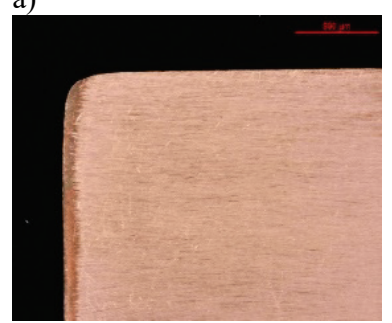

d)

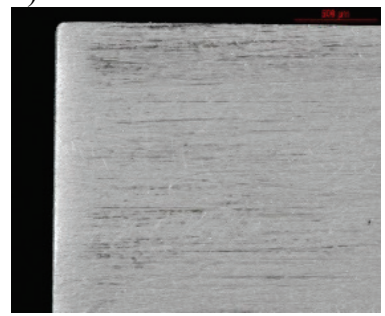

b)

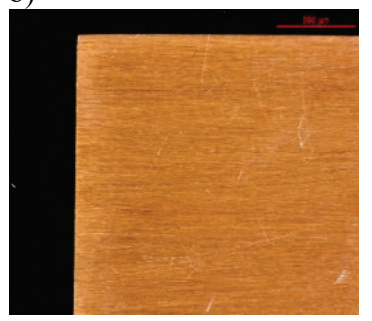

e)

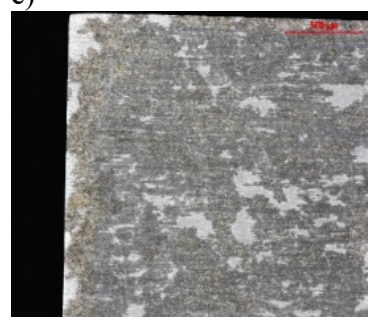

c)

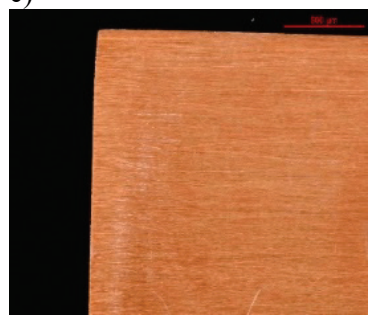

f)

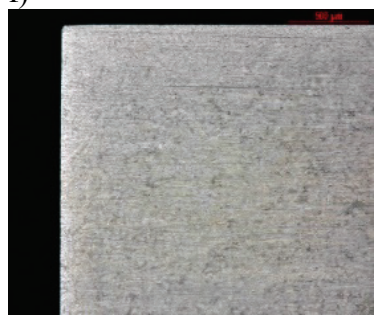

Fig. 1. Morphology of the studied plates, scale $500 \mu \mathrm{m}$; copper plate before the test (a); copper plate after the test, immersed in antifreeze including inorganic additives (b); copper plate after the test, immersed in antifreeze comprising organic additives (c); aluminium plate before the test (d), aluminium plate after the test, immersed in antifreeze comprising inorganic additives (e), aluminium plate after the test, immersed in antifreeze with organic additives (f). Test conditions: temperature $86-90^{\circ} \mathrm{C}$, airflow $90-110 \mathrm{ml} / \mathrm{min}$, test time- 14 days

\section{Copper plates:}

- morphologic changes on copper plates subjected to corrosion were not observed,

- plate b-slight tarnish and colour change to orange,

- plate c-colour change to orange.

\section{Aluminium plates:}

- across the entire surface of the plate, evenly distributed, irregularly shaped, dark grey zones connected to each other were detected - plate coverage degree approx. $90 \%$,

- the surface of plate f as compared to d - slight tarnish is observed - no morphological changes are found.

The microscopic examination is conducted according to the above-mentioned methodology. 


\section{Copper plates:}

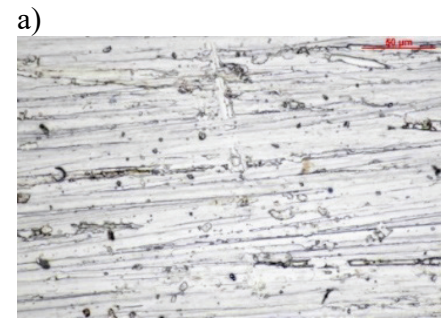

b)

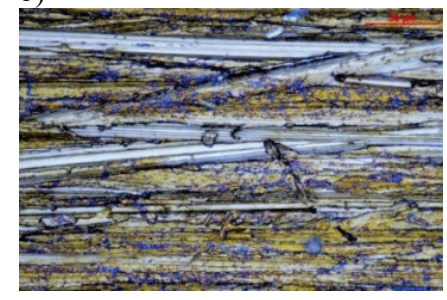

d)

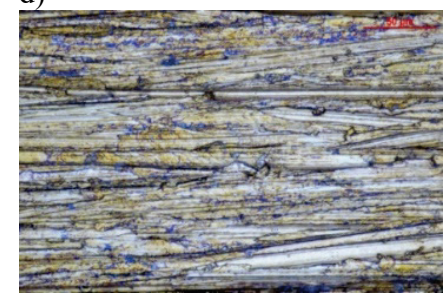

c)

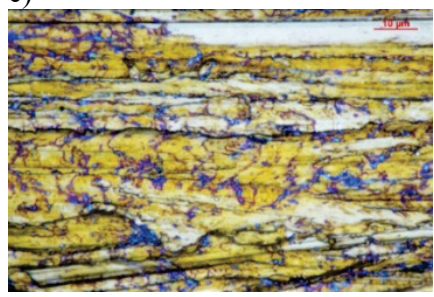

e)

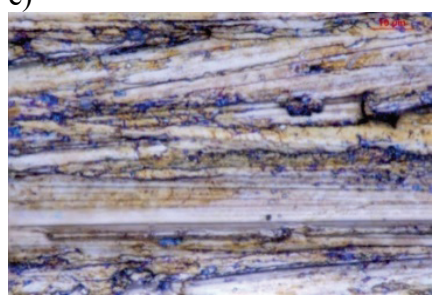

Fig. 2. $\mathrm{Cu}$ plates: a) plate before the test, $\mathrm{BF}, 50 \times 10$, scale $50 \mu \mathrm{m}$; b) plate after the test, immersed in a liquid containing inorganic additives, BF, 50x10, scale $50 \mu \mathrm{m}$; c) plate after the test, immersed in a liquid comprising inorganic additives, BF, 150x10, scale $10 \mu \mathrm{m}$; d) plate after the test, immersed in a liquid with organic additives, BF, 50x10, scale $50 \mu \mathrm{m}$; e) plate after the test, immersed in a liquid containing organic additives, $\mathrm{BF}, 150 \times 10$, scale $10 \mu \mathrm{m}$

The micro-images of the copper plate surfaces revealed the following:

- Visible traces of mechanical treatment (scratches and furrows with the width of $10 \ldots 20 \mu \mathrm{m})$, lack of corrosion traces on the 'reference' surface of the plate not exposed to corrosion attack (fig. 2a).

- The presence of irregular yellow discolorations on plates exposed to corrosion in a liquid with inorganic additives (fig. 2b-c). In these areas, there are characteristic groups of point objects ( $\operatorname{size}<1 \mu \mathrm{m}$ ) in light blue colour. They can be mainly seen in micro deformation zones of the surface with potentially higher stress and energy.

- The presence of irregular yellow discolorations on plates subjected to corrosion in a liquid including organic additives (fig. $2 \mathrm{~d}$-e). They are very similar in nature but smaller and less intense than in plates $b$ and $c$. These areas also have characteristic groups of point objects (size $<1 \mu \mathrm{m}$ ) in light blue colour. They can be mainly seen in micro deformation zones of the surface with potentially higher stress and energy. 


\section{Aluminium plates:}

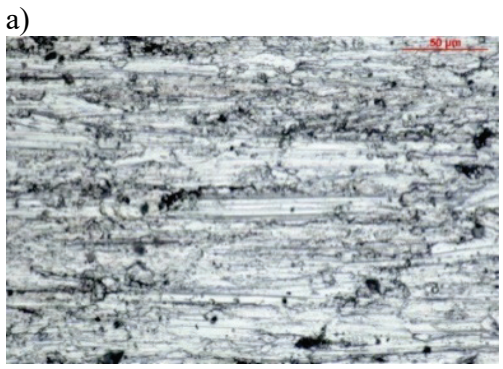

b)

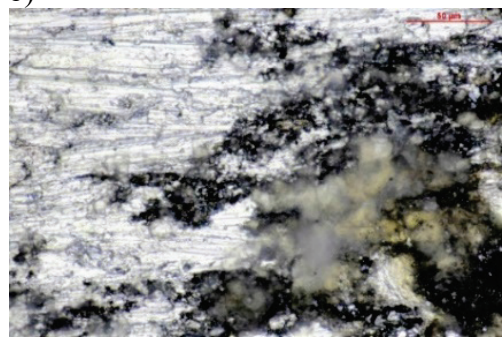

d)

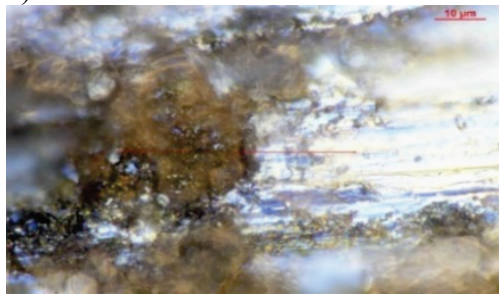

f)

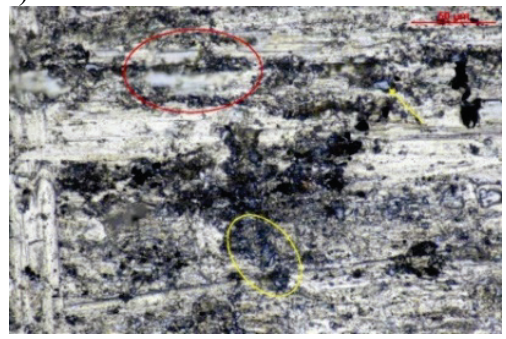

c)

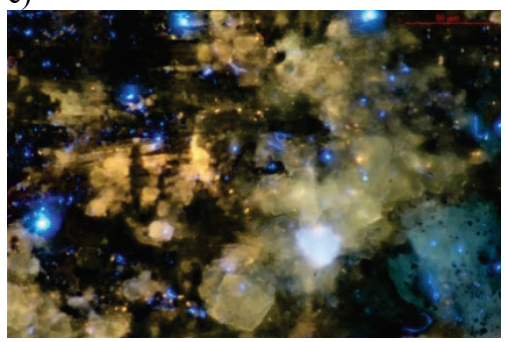

e)

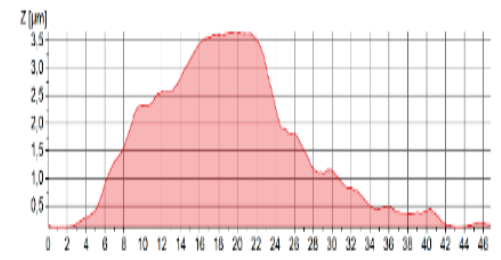

$|\mathrm{m}|$

g)

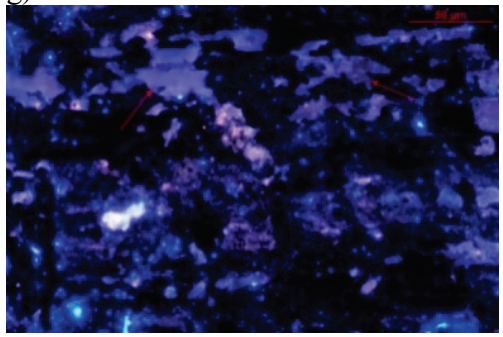

Fig. 3. Al plates: a) plate before the test, $\mathrm{BF}, 50 \times 10$, scale $50 \mu \mathrm{m}$; b) plate after the test, immersed in a liquid with inorganic additives, $\mathrm{BF}, 50 \times 10$, scale $50 \mu \mathrm{m}$; c) plate after the test, immersed in a liquid with inorganic additives, FLUO 1, 50x10, scale $50 \mu \mathrm{m}$; d) plate after the test, immersed in a liquid containing inorganic additives, DIC, 150x10, scale $10 \mu \mathrm{m}$; e) red line height profile on image d); f) plate after the test, immersed in a liquid with organic additives, $\mathrm{BF}, 50 \times 10$, scale $50 \mu \mathrm{m}$; g) plate after the test in a liquid with organic additives, FLUO 1, $50 \mathrm{x} 10$, scale $50 \mu \mathrm{m}$ 
h)

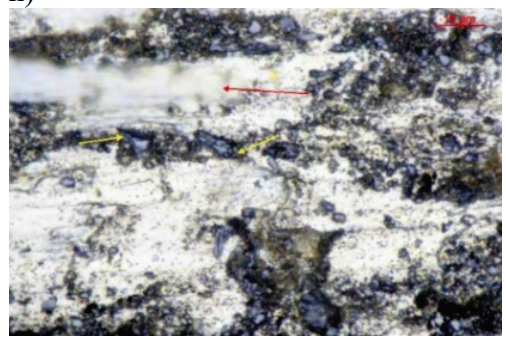

i)

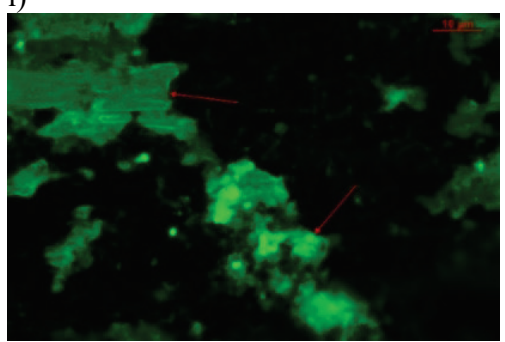

Fig. 3. cont. Al plates: h) plate after the test in a liquid comprising organic additives, $\mathrm{BF}, 150 \times 10$, scale $10 \mu \mathrm{m}$; i) plate after the test, immersed in a liquid with organic additives, FLUO $2,150 \times 10$, scale 10

The micro-images of the surfaces of aluminium plates revealed the following:

- Visible traces of mechanical treatment (scratches and furrows with the width of $10 \ldots 20 \mu \mathrm{m})$, lack of corrosion traces on the 'reference' surface of the plate not exposed to the corrosion attack (fig. 3a.).

- The impact of the liquid including inorganic additives results in the presence of non-continuous, local layers on the surface of the plate $(b, c, d)$. They are partially transparent, especially in bright field technique (b, d), in yellow colour. Moreover, they are clearly visible in the fluorescence technique (c). The thickness of these layers is approx. 3-4 $\mu \mathrm{m}$ (profile in 3e along the lines in $3 \mathrm{~d}$ ).

- The impact of the liquid containing organic additives results in the presence of noncontinuous, local layers on the surface of the plate. In the bright field techniques, they are transparent ( $\mathrm{f}, \mathrm{h}$ - arrow and red fields). These layers are clearly visible in the fluorescence technique ( $\mathrm{g}, \mathrm{i}$ - red arrows).

- The influence of the liquid comprising organic additives also results in relative even occurrence of many grey objects of crystalline nature with dimensions below $10 \mu \mathrm{m}$ (f, h, arrows and yellow field).

\section{Conclusions and summary}

The quality specification to be complied by ICECS antifreeze liquids is defined in the standard [5]. The norm provides research methods, according to which individual properties shall be examined. Among the methods mentioned, there is also a standard technique of corrosive effect assessment of antifreeze liquids based on glycols used in internal combustion engine cooling systems [6].

This gravimetric analysis is used to identify corrosion changes characterized by even or uneven loss of the metal surface layer due to the interaction with aggressive environmental components. The standard also defined the requirements on the absence of corrosion pits, but this estimation method was not determined. 
Usually, corrosion pits occur locally. The change in the mass of corrosion pits may be insignificant, but the proceeding defect can contribute to perforation and damage to their elements.

The lack of the evaluation criteria specified in the standard in terms of the presence of corrosion pits allows performing macro-scale visualization inspection. The macroscopic examination revealed objects of about tenths of a millimetre, but the propagation of pitting corrosion occurs usually by the propagation of corrosion pits formed already during nucleation. Corrosion seeds, not detectable with macroscopic techniques, can pose a risk of corrosion propagation over the long service life, which is predicted for infrastructure HVAC systems.

The weight loss in copper plates did not indicate the signs of corrosion according to the adopted criteria of gravimetric assessment. The macroscopic visual inspection enabled to observe that copper plates immersed in both types of antifreeze changed its colour to intense orange. On a plate immersed in a liquid containing inorganic additives, slight tarnish of the surface was observed. Copper changes its colour to orange due to the oxidation process, and it results from energy differences corresponding to the wavelength of orange light between valence shells of copper - fully filled $3 \mathrm{~d}$ coating and partially filled 4 s coating. In the micro-scale, on the surface of copper plates tested in two types of fluids are seen numerous discolorations and presumably, very fine $(<1 \mu \mathrm{m})$ oxidation products, found in places of stress concentration. In the micro-scale, it can be noted that the impact of the liquid sample comprising organic additives is less intense as compared to the liquid with inorganic additives.

Copper corrosion might initiate in some unfavourable conditions in the form of surface alterations. Corrosion pits are formed under the impact of some simultaneous unfavourable factors and are the result of the formation of the protective layer. The $\mathrm{pH}$ of water is of key importance in the formation of corrosion pits in copper. High $\mathrm{pH}$, with the value above 8 , which occurs in many antifreeze liquids, favours the formation of corrosion pits.

Aluminium is characterized by lower electrochemical potential than the majority of typical construction metals; thus, the risk of its exposure to electrochemical corrosion is higher than in the case of, e.g. copper or steel. The surface of aluminium plates tested in a liquid containing inorganic additives was covered with the dark deposit, which is visible in the macro-scale. In the case of these plates, the highest average increment of mass was observed, but the mass of plates after the test did not exceed the upper limit of the adopted acceptance criterion.

In the macroscopic examination, no corrosion changes were found. It was due to the action of a fluid comprising inorganic additives. In the micro-scale, it was noted that the action of a fluid containing inorganic additives resulted in the formation of discontinuous layers on the surface of aluminium plates.

Due to electrochemical processes occurring in the cell with the embedded aluminium electrode, aluminium ions could appear in the solution. These ions are capable of creating complex compounds in the aqueous environment. Inorganic corrosion inhibitors in antifreeze are silicates and nitrites. The characteristic feature of silicates is their ability to 
form aluminosilicates. This is done by coordinating the aluminium atoms by the central silicate atom, which is connected by strong sigma bonds with four oxygen atoms in the crystal lattice, creating the configuration of a tetrahedron. Both complex compounds and aluminosilicates can form durable coatings with significant resistance.

The surface of aluminium plates reacting with the liquid comprising organic corrosion inhibitors was not covered with a layer clearly visible in a macro-scale. In the micro-scale, it was observed that the influence of the sample containing organic additives resulted in the presence of a fine fraction of crystalline molecules on the surface of the aluminium plate. Crystalline nuclei that form on the metal surface may disturb its ordered structure and can lead to the intensification at the place of their occurrence, and thus, they can increase the risk of corrosion.

Standard research methods are used to efficiently control the quality of antifreeze intended for ICECS. The complex composition of antifreeze is composed in such a way as to ensure proper protection of construction metals in vehicles and devices, the projected life of which is much shorter than the service life of infrastructure heat exchangers in industry and construction. The microscopic techniques used in the study enabled us to discover various alterations on metal surfaces, which may provide valuable information for investors at the stage of designing the installation and selecting the appropriate working medium for filling infrastructure HVAC systems.

\section{References}

1. https://alpari.net.pl/blog-motoryzacyjny/item/12-plyn-chlodzacy, access 05.06.2019.

2. https://www.auto-swiat.pl/porady/eksploatacja/jak-dobrac-odpowiedni-plynchlodniczy/ serrpsh, access 05.06.2019.

3. https://www.valvoline.com/our-products/antifreeze-products/antifreezeeducation/engine-coolant, access 26.11.2019.

4. Łobodziński M.: Płyny chłodnicze - skład, rodzaje i eksploatacja. https://autokult.pl/2217,plyny-do-chlodnic-samochodowych-sklad-rodzaje-i-eksploatacja, access 26.11.2019.

5. Norma PN/C-40007:2000 - Płyny niskokrzepnące do układów chłodzenia silników spalinowych - Wymagania i badania.

6. Norma PN-C-40008/07 + PN-C-40008/07/Az1:2000 Płyny niskokrzepnące do układów chłodzenia silników spalinowych - Badanie właściwości korozyjnych w naczyniu szklanym.

7. Tang Z.: A review of corrosion inhibitors for rust preventative fluids. Current Opinion and Solid State \& Materials Science, Vol. 23, 2019.

8. Wojciechowski J.: Rola związków krzemoorganicznych w ochronie metali oraz stali przed korozją elektrochemiczną. Politechnika Poznańska, Wydział Technologii Chemicznej, rozprawa doktorska, Poznań 2019. 


\section{OCENA WPLYWU GLIKOLOWYCH PLYNÓW CHLODZĄCYCH NA POWIERZCHNIE TYPOWYCH MATERIALÓW KONSTRUKCYJNYCH WYMIENNIKÓW CIEPLA}

\section{Wprowadzenie i cel pracy}

W konstrukcjach metalowych, w których czynnikiem roboczym są płyny na bazie glikoli, dominującym typem procesu degradującego metalowe elementy jest korozja elektrochemiczna. Stykające się ze sobą metale, z jakich wykonane są poszczególne elementy, różnią się między sobą wartością potencjałów elektrochemicznych i tworzą ogniwo, w którym glikolowy czynnik roboczy odgrywa rolę elektrolitu [7,8]. Na powierzchni metalu o niższym potencjale elektrochemicznym zachodzą procesy utleniania. Anoda odbiera elektrony i sprawia, że dodatnie jony przedostają się do roztworu elektrolitu. W obszarze katodowym następuje wiele złożonych procesów redukcji, a ich finalny efekt zależy od rodzaju materiałów tworzących ogniwo oraz od składu chemicznego elektrolitu.

Normy definiujące metody oceny korozyjnego działania płynów na bazie glikoli [6] oraz wymagania w tym zakresie [5] zostały opracowane do badania płynów działających w układach chłodzenia silników spalinowych (ICECS - Internal Combustion Engine Cooling System). Praktyka eksploatacyjna pokazuje, że czas użytkowania infrastrukturalnych systemów grzania, chłodzenia i wentylacji (HVAC - Heat, Ventilation, Air Conditioning) jest jednak znacznie dłuższy w porównaniu z czasem eksploatacji silników spalinowych. Ze względu na wydłużony okres eksploatacji, narażenie materiałów konstrukcyjnych na agresywne środowisko glikolowego czynnika roboczego trwa znacznie dłużej w przypadku systemów infrastrukturalnych.

Normatywne badanie korozji jest pewną symulacją przyspieszającą procesy, które w rzeczywistych warunkach pracy układu chłodzenia silnika spalinowego, postępują stopniowo. Oceny zmian korozyjnych wywołanych działaniem płynów niskokrzepnących do układów chłodzenia silników spalinowych przeprowadza się metodą wagową. Obecność wżerów korozyjnych ocenia się w makroskali, stosując metodę wizualną.

Powszechnie przyjmuje się, że niezależnie od przeznaczenia płynu, badania wykonywane są jednakowymi metodami. Znormalizowane sposoby oceny zmian korozyjnych metodami wagową oraz wizualną w makroskali, pozwalają w sposób zadowalający oszacować ryzyko korozyjne związane z krótszym czasem eksploatacji ICECS. Można jednak założyć, że w symulowanych warunkach badania, na powierzchniach metalowych płytek 
testowych pojawiają się mikrozmiany, które nie muszą mieć istotnego znaczenia w przypadku krótszego okresu eksploatacji ICECS, lecz mogą oznaczać ryzyko korozji z punktu widzenia długookresowej eksploatacji HVAC. W tym kontekście ocena wagowa połączona z oceną wżerów korozyjnych przeprowadzoną wyłącznie w makroskali może nie stanowić kompleksowej informacji na temat zagrożenia korozją systemów HVAC.

Celem niniejszej pracy było zbadanie, czy ocena zagrożenia korozyjnego metodą znormalizowaną dla płynów niskokrzepnących do ICECS może być miarodajnym i w pełni wystarczającym sposobem oceny korozyjnego działania tych płynów w przypadku, gdy będą one stanowiły czynnik roboczy w infrastrukturalnych wymiennikach ciepła. Przebadano dwa rodzaje płynów niskokrzepnących o odmiennych kompozycjach. Zidentyfikowano i porównano struktury powstałe pod ich wpływem na powierzchniach dwóch wybranych typów metali, znajdujących się w grupie podstawowych materiałów konstrukcyjnych wykorzystywanych do budowy infrastrukturalnych wymienników ciepła.

\section{Metodyka i przebieg badań}

Obiektem badań były próbki dwóch płynów niskokrzepnących na bazie glikolu etylenowego, zawierające odmienne pakiety dodatków antykorozyjnych. Próbka 1 zawierała w swoim składzie pakiet antykorozyjny, składający się z dodatków nieorganicznych (stosowany w płynach dedykowanych do starszych typów pojazdów), formuła drugiej próbki oparta była na nowszej technologii dodatków organicznych. [1-4].

Badanie polegające na kontaktowaniu „kostki”, wykonanej z sześciu metali połączonych w ogniwo, z badanym płynem, w podwyższonej temperaturze wykonano zgodnie z normą wykonawczą [6]. W niniejszych badaniach wykorzystano gatunki materiałów konstrukcyjnych stosowane w standardowych, znormalizowanych testach właściwości korozyjnych płynów niskokrzepnących do układów chłodzenia silników spalinowych. Badanie prowadzono w temperaturze $86-90^{\circ} \mathrm{C}$, w sposób ciągły przez 336 godzin. W trakcie badania przez badany płyn przepuszczane było powietrze o przepływie $90-110 \mathrm{~cm}^{3} / \mathrm{min}$.

W ramach oceny normatywnej wykonano analizę wagową, która polegała na wyznaczeniu różnicy mas płytek po badaniu względem ich mas przed badaniem. Ocena zmiany masy płytek testowych została przeprowadzona według kryteriów określonych w normie dla płynów niskokrzepnących do układów chłodzenia silników spalinowych. Bazując na dokumencie normatywnym [6] przyjęto, że przy zmianie masy płytki miedzianej o więcej niż $10 \mathrm{mg}$ i płytki aluminiowej o więcej niż $30 \mathrm{mg}$ należy uznać działanie płynu niskokrzepnącego za korozyjne.

W celu identyfikacji wżerów korozyjnych zastosowano metody wizualne. Wizualną ocenę makroskopową powierzchni płytek przeprowadzono w komorze bezcieniowej za pomocą makrofotografii wykonanych aparatem Nikon D7200 z obiektywem Nikkor AF-S Micro Nikkor 105. Oceny mikroskopowej dokonano za pomocą mikroskopu Nikon LV100ND, wyposażonego w kamerę cyfrową Nikon DS-Ri2 i oprogramowanie NIS BR. Zastosowano następujące techniki obserwacji EPI (przy świetle odbitym): 
- jasne pole - BF,

- fluorescencja - FLUO 1 (filtr UV-2A), FLUO 2 (filtr GFP-B),

- kontrast DIC Nomarskiego - DIC.

Technika jasnego pola (BF) umożliwia identyfikację obiektów o różnej zdolności odbijania i rozpraszania wiązki światła, padającej prostopadle do badanej powierzchni próbki. Dobrze widoczne są obiekty o różnej barwie, nieprzezroczyste, o wyraźnych konturach. Widoczne są również deformacje (nierówności, wgłębienia) na badanej powierzchni próbki, które rozpraszając część wiązki świetlnej, będą ciemniejsze. Technika ta umożliwiła identyfikację potencjalnych obiektów o charakterze powłok, osadów, wydzieleń, przebarwień i wżerów.

Technika fluorescencji (FLUO) wykorzystuje zjawisko fluorescencji - emisji światła przez wzbudzone cząstki badanego obiektu. Wykorzystuje przesunięcie pasma emisji w kierunku większych długości fali względem pasma absorpcji. W badaniach wykorzystano następujące filtry fluorescencyjne:

- FLUO 1 (filtr UV-2A) - pasmo wzbudzenia 330-380 nm, pasmo emisji $>420 \mathrm{~nm}$,

- FLUO 2 (filtr GFP-B) - pasmo wzbudzenia 450-490 nm, pasmo emisji $510-560 \mathrm{~nm}$.

Umożliwiła również obserwację przezroczystych w BF warstw na powierzchni badanych płytek.

Technika kontrastu DIC Nomarskiego poprzez wykorzystanie światła spolaryzowanego i specjalnej konstrukcji pryzmatu Wolstona-Nomarskiego umożliwiła uzyskanie quasi przestrzennego obrazu powierzchni badanych płytek. Pozwala to na lepsze zobrazowanie topografii badanych powierzchni - grubości potencjalnych warstw lub głębokości wżerów.

\section{Wyniki}

Konstrukcja typowego wymiennika ciepła stosowanego w infrastrukturalnych systemach grzania i chłodzenia, w którym jako medium robocze wykorzystuje się roztwory glikoli, składa się przeważnie $\mathrm{z}$ miedzianej wężownicy, osadzonej w wykonanych $\mathrm{z}$ aluminium, lamelach, dlatego te dwa typy materiałów zostały poddane w pierwszej kolejności ocenie w przedstawianych badaniach.

Średnia zmiana masy płytek została oszacowana na podstawie pomiarów płytek pochodzących z trzech jednakowo zmontowanych zestawów testowych opisanych w pkt 2. Średnie wartości zmiany masy płytek badanych w płynie zawierającym dodatki nieorganiczne i odpowiednio w płynie z dodatkami organicznymi przedstawia tabela 1 . 
Tabela 1

Średnia zmiana masy (w mg) płytek metalowych po 336 godzinach oddziaływania z roztworem płynu niskokrzepnącego w temperaturze $86-90^{\circ} \mathrm{C}$, przy przepływie powietrza $90-110 \mathrm{ml} / \mathrm{min}$. Średnia obliczona na podstawie wyników uzyskanych dla 3 płytek. Wynik dla aluminium podany przed i po trawieniu w roztworze kwasu azotowego

\begin{tabular}{|l|l|l||}
\hline Płóbka & $\begin{array}{l}\text { Średnia zmiana masy płytek } \\
\text { badanych w próbce } \\
\text { zawierającej dodatki } \\
\text { nieorganiczne } \\
{[\mathrm{mg}]}\end{array}$ & $\begin{array}{l}\text { Średnia zmiana masy płytek } \\
\text { badanych w próbce } \\
\text { zawierającej dodatki } \\
\text { organiczne } \\
{[\mathrm{mg}]}\end{array}$ \\
\hline $\mathrm{Cu}$ & $-0,1$ & $-0,1$ \\
\hline $\mathrm{Al}$ & $+29,0 /+0,7$ & $+3,6 /-2,3$ \\
\hline
\end{tabular}

Wysoki średni przyrost masy zaobserwowano w przypadku płytek aluminiowych, które stanowiły element ogniwa oddziałującego z roztworem płynu zawierającego dodatki nieorganiczne. Średni przyrost masy płytki aluminiowej badanej w środowisku płynu, zawierającego dodatki organiczne był około ośmiokrotnie mniejszy niż płytki, na którą oddziaływał płyn z dodatkami nieorganicznymi.

W przypadku powstania grubych warstw osadu na płytkach testowych norma wykonawcza zaleca usunięcie jego nadmiaru przez oczyszczenie szczoteczką z miękkim włosiem i zanurzenie w roztworze kwasu azotowego o stężeniu ok. $12 \mathrm{~mol} / \mathrm{dm}^{3}$ przez 10 minut w temperaturze pokojowej. Następnie opłukanie w wodzie destylowanej i osuszenie w strumieniu powietrza [6]. W celu usunięcia bariery depozytowej powstałej na płytkach aluminiowych badanych w płynie zawierającym dodatki nieorganiczne, która w istotny sposób utrudniała wizualizację mikroskopową ewentualnych zmian korozyjnych, zabieg wykonano. Następnie powtórnie przeprowadzono pomiar masy oraz oszacowano zmianę w odniesieniu do płytki przed badaniem.

Przykładowe powierzchnie płytek testowych uzyskanych w wyniku makroskopowej oceny wizualnej przedstawiono na rys. 1 . 
a)

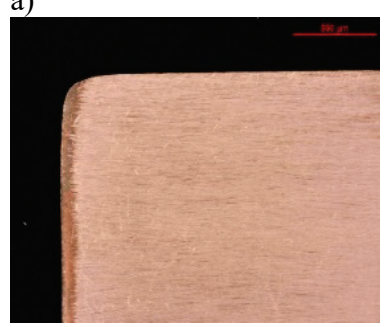

d)

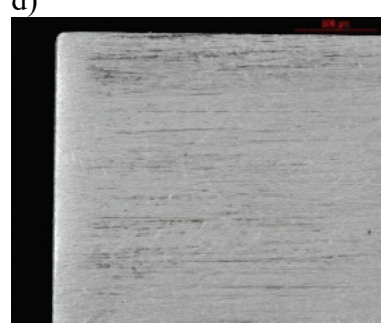

b)

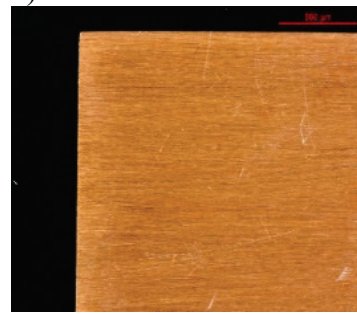

e)

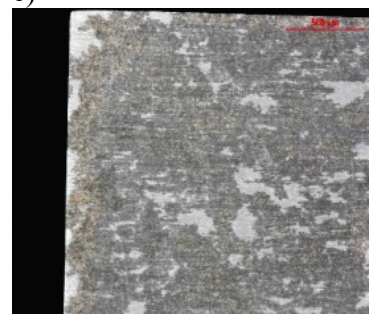

c)

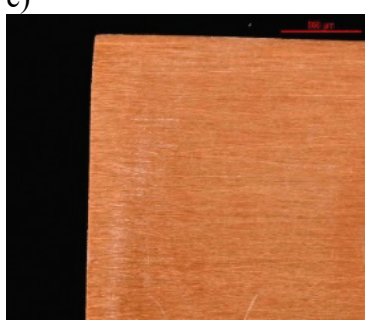

f)

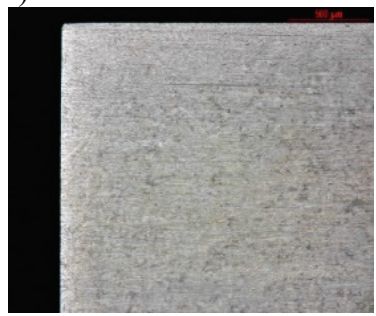

Rys. 1. Morfologia badanych płytek, skala $500 \mu \mathrm{m}$; płytka miedziana przed badaniem (a); płytka miedziana po badaniu w płynie niskokrzepnącym zawierającym dodatki nieorganiczne (b); płytka miedziana po badaniu w płynie niskokrzepnącym zawierającym dodatki organiczne (c); płytka aluminiowa przed badaniem (d), płytka aluminiowa po badaniu w płynie niskokrzepnącym zawierającym dodatki nieorganiczne (e), płytka aluminiowa po badaniu w płynie niskokrzepnącym zawierającym dodatki organiczne (f). Warunki badania: temperatura $86-90^{\circ} \mathrm{C}$, przepływ powietrza $90-110 \mathrm{ml} / \mathrm{min}$, czas badania $14 \mathrm{dni}$

\section{Plytki miedziane:}

- nie zaobserwowano zmian morfologicznych na płytkach miedzianych poddanych korozji,

- płytka b - niewielkie zmatowienie i zmiana barwy na pomarańczową,

- płytka c - zmiana barwy na pomarańczową.

\section{Plytki aluminiowe:}

- na całej powierzchni płytki e stwierdzono równomiernie rozłożone, ciemnoszare obszary o nieregularnym kształcie, łączące się ze sobą - stopień pokrycia płytki ok. $90 \%$,

- powierzchnia płytki f w stosunku do d niewielkie zmatowienie - nie zaobserwowano zmian w morfologii.

Oceny mikroskopowej przeprowadzono zgodnie z przedstawioną wyżej metodyką. 


\section{Plytki miedziane}

a)

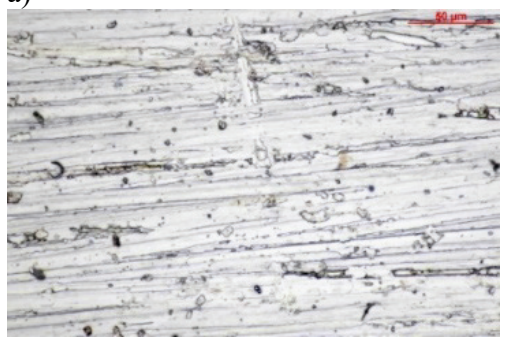

b)

c)

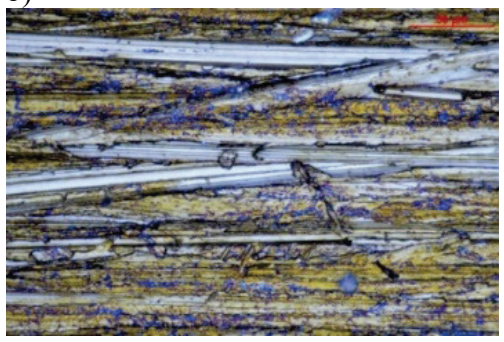

d)

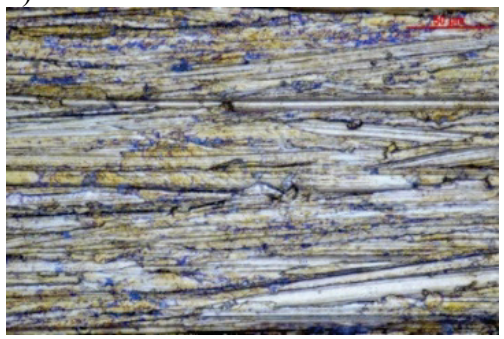

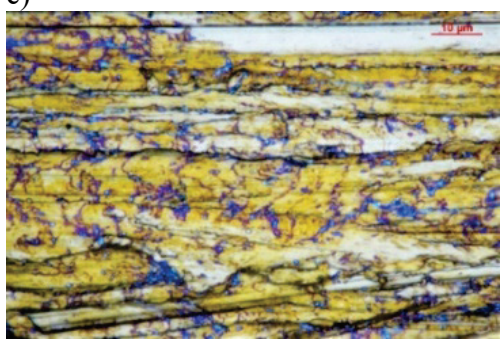

e)

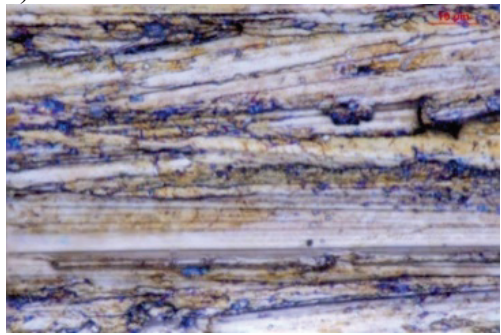

Rys. 2. Płytki Cu: a) płytka przed badaniem, BF, 50x10, skala $50 \mu \mathrm{m}$; b) płytka po badaniu w płynie zawierającym dodatki nieorganiczne, $\mathrm{BF}, 50 \times 10$, skala $50 \mu \mathrm{m}$; c) płytka po badaniu w płynie zawierającym dodatki nieorganiczne, $\mathrm{BF}, 150 \times 10$, skala $10 \mu \mathrm{m}$; d) płytka po badaniu w płynie zawierającym dodatki organiczne, $\mathrm{BF}, 50 \times 10$, skala $50 \mu \mathrm{m}$; e) płytka po badaniu w płynie zawierającym dodatki organiczne, $\mathrm{BF}, 150 \mathrm{x} 10$, skala $10 \mu \mathrm{m}$

Na mikrofotografiach powierzchni płytek miedzianych zaobserwowano:

- Widoczne ślady po obróbce mechanicznej (rysy i bruzdy o szerokości 10..20 $20 \mathrm{~m}$ ) i brak śladów korozji na powierzchni ‘odniesienia' płytki niepoddanej procesowi korozji (rys. 2a).

- Obecność nieregularnych przebarwień w odcieniu żółci na płytkach poddanych korozji w płynie zawierającym dodatki nieorganiczne (rys. 2b-c). W tych obszarach występują charakterystyczne grupy punktowych obiektów (rozmiar $<1 \mu \mathrm{m}$ ) w kolorze jasnoniebieskim. Występują one głównie w strefach mikro deformacji powierzchni o potencjalnie większym naprężeniu i energii. 
- Obecność nieregularnych obszarów w odcieniu żółci, o niezdefiniowanej grubości na płytkach poddanych korozji w płynie zawierającym dodatki organiczne (rys. 2de). Mają bardzo podobny charakter, ale są mniejsze i mniej intensywne niż w przypadku płytek b i c. W tych obszarach również występują charakterystyczne grupy punktowych obiektów (rozmiar $<1 \mu \mathrm{m}$ ) w kolorze jasnoniebieskim. Występują one głównie w strefach mikro deformacji powierzchni o potencjalnie większym naprężeniu i energii.

\section{Plytki aluminiowe:}

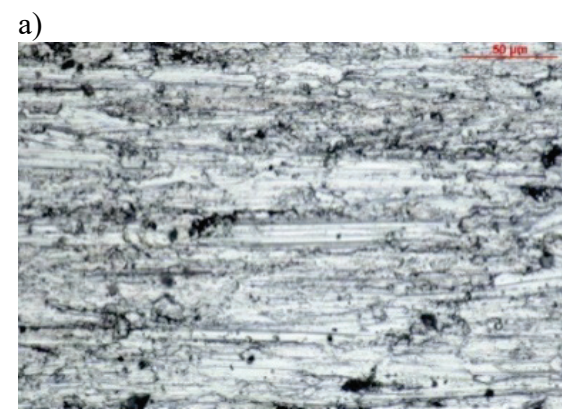

b)

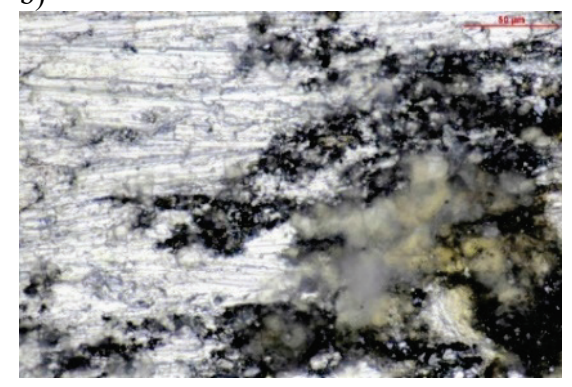

d)

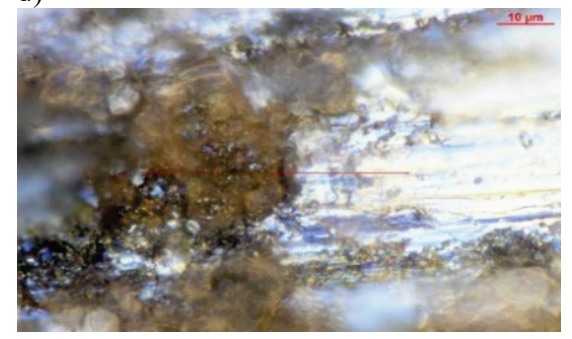

c)

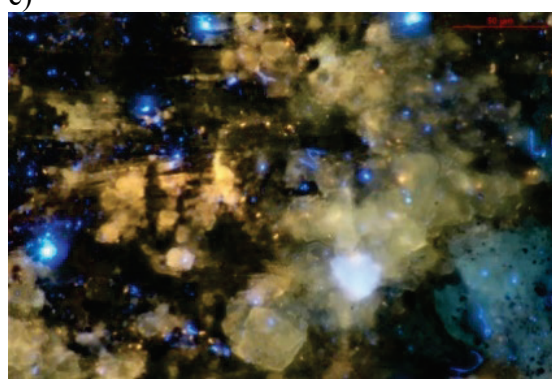

e)

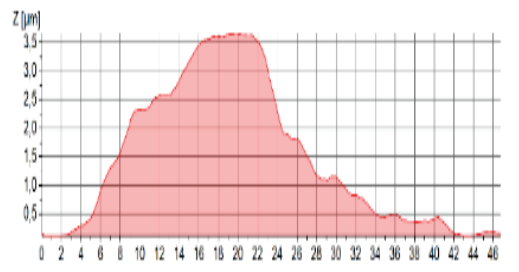

Rys. 3. Płytki Al.: a) płytka przed badaniem, BF, $50 \times 10$, skala $50 \mu \mathrm{m}$; b) płytka po badaniu w płynie zawierającym dodatki nieorganiczne, BF, $50 \times 10$, skala $50 \mu \mathrm{m}$; c) płytka po badaniu w płynie zawierającym dodatki nieorganiczne, FLUO 1, 50x10, skala $50 \mu \mathrm{m}$; d) płytka po badaniu w płynie zawierającym dodatki nieorganiczne, DIC, 150x10, skala $10 \mu \mathrm{m}$; e) profil wysokości wg czerwonej linii na fotografii d) 
f)

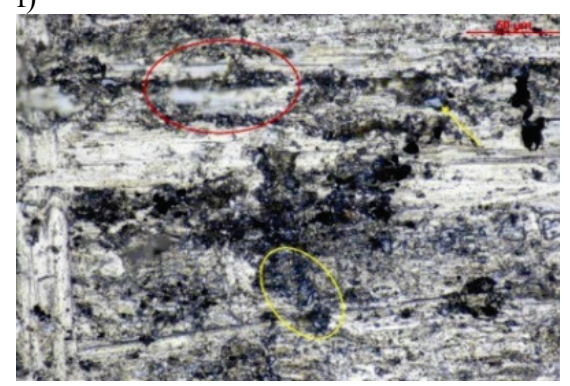

h)

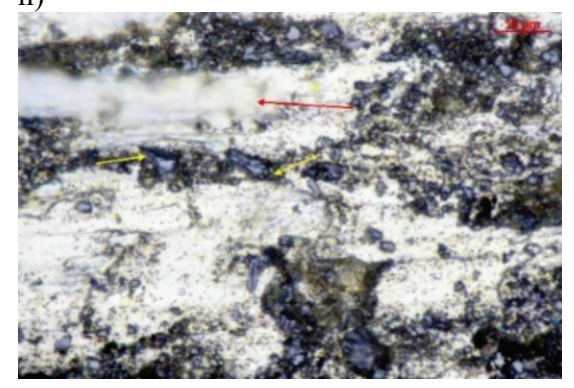

g)

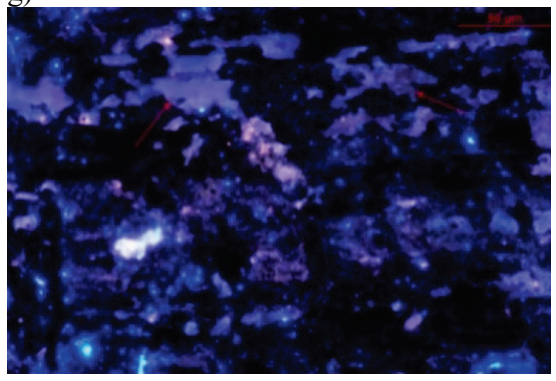

i)

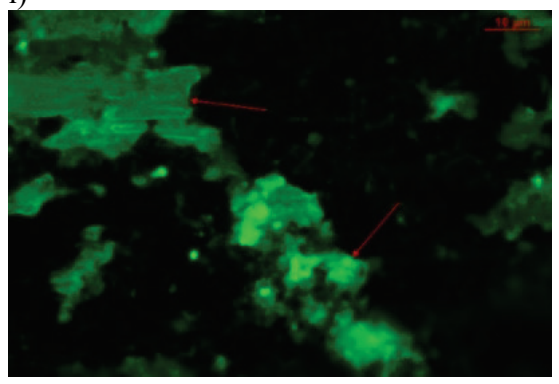

Rys. 3. cd. Płytki Al.: f) płytka po badaniu w płynie zawierającym dodatki organiczne, BF, 50x10, skala $50 \mu \mathrm{m}$; g) płytka po badaniu w płynie zawierającym dodatki organiczne, FLUO 1, 50x10, skala $50 \mu \mathrm{m}$; h) płytka po badaniu w płynie zawierającym dodatki organiczne, $\mathrm{BF}, 150 \times 10$, skala $10 \mu \mathrm{m}$; i) płytka po badaniu w płynie zawierającym dodatki organiczne, FLUO 2, 150x10, skala $10 \mu \mathrm{m}$

Na mikrofotografiach powierzchni płytek aluminiowych zaobserwowano:

- Widoczne ślady po obróbce mechanicznej (rysy i bruzdy o szerokości 10..20 $\mu \mathrm{m}$ ) i brak śladów korozji na powierzchni 'odniesienia' płytki niepoddanej procesowi korozji rys. 3a.

- Oddziaływanie płynu zawierającego dodatki nieorganiczne skutkuje obecnością nieciągłych, lokalnych warstw na powierzchni płytki (b, c, d). Są one częściowo przezroczyste, szczególnie w technice jasnego pola (b, d), w odcieniu żółci. Widoczne są dobrze $\mathrm{w}$ technice fluorescencji (c). Grubość tych warstw to ok. 3-4 $\mu \mathrm{m}$ (profil na 3e wzdłuż linii na 3d).

- Oddziaływanie płynu zawierającego dodatki organiczne skutkuje obecnością nieciągłych, lokalnych warstw na powierzchni płytki. W technice jasnego pola są one przezroczyste ( $\mathrm{f}, \mathrm{h}$ - strzałka i pole czerwone). Warstwy te widoczne są dobrze w technice fluorescencji ( $\mathrm{g}, \mathrm{i}$ - czerwone strzałki).

- Oddziaływanie płynu zawierającego dodatki organiczne skutkuje również stosunkowo równomiernym występowaniem wielu obiektów o charakterze krystalitów w kolorze szarym, o wymiarach poniżej $10 \mu \mathrm{m}$ (f, h, strzałki i pole żółte). 


\section{Wnioski i podsumowanie}

Specyfikacja jakościowa, jaką powinny spełniać płyny niskokrzepnące do ICECS zdefiniowana jest w normie [5]. Norma przywołuje metodyki badawcze, według których należy dokonać oceny poszczególnych właściwości. Wśród przywołanych metod funkcjonuje znormalizowana technika oceny korozyjnego działania płynów niskokrzepnących na bazie glikoli do układów chłodzenia silników spalinowych [6].

Przywołana w normie metoda wagowa jest stosowana do identyfikacji zmian korozyjnych charakteryzujących się równomiernym, bądź nierównomiernym ubytkiem warstwy wierzchniej metalu na skutek reakcji z agresywnymi składnikami środowiska. W normie zdefiniowano również wymaganie dotyczące braku obecności wżerów korozyjnych, jednak nie została sprecyzowana metoda przeprowadzenia tej oceny.

Wżery korozyjne występują zwykle lokalnie. Zmiana masy w przypadku wżerów korozyjnych może być niewielka, ale postępujące uszkodzenia mogą w dłuższym okresie prowadzić do perforacji i zniszczenia elementu.

Brak sprecyzowanych w normie kryteriów oceny pod kątem obecności wżerów korozyjnych dopuszcza możliwość wykonywania wizualizacji w makroskali. Ocena makroskopowa pozwala ujawniać obiekty wielkości około dziesiątych części milimetra, tymczasem rozwój korozji wżerowej zachodzi zwykle poprzez rozrost wżerów tworzących się już na etapie zarodkowania. Zalążki korozji, które nie są możliwe do wykrycia technikami makroskopowymi, mogą stwarzać ryzyko rozwoju korozji w tak długich okresach eksploatacji, jakie są prognozowane dla infrastrukturalnych systemów HVAC.

Ubytki masy płytek wykonanych z miedzi nie wskazywały na pojawienie się znamion korozji według przyjętych kryteriów oceny wagowej. Makroskopowa metoda wizualna pozwoliła zaobserwować głównie zmianę barwy płytek miedzianych badanych w obydwu rodzajach płynów niskokrzepnących na intensywniej pomarańczową. W przypadku płytki badanej w płynie zawierającym dodatki nieorganiczne zaobserwowano dodatkowo lekkie zmatowienie powierzchni. Zmiana barwy miedzi na pomarańczową następuje w procesie utleniania i wynika $\mathrm{z}$ różnic energetycznych odpowiadających długości fali światła pomarańczowego pomiędzy powłokami walencyjnymi miedzi - w pełni zapełnioną powłoką $3 \mathrm{~d}$ oraz częściowo zapełnioną powłoką $4 \mathrm{~s}$. W skali mikro na powierzchni płytek miedzianych, badanych w obu rodzajach płynów, zaobserwowano liczne przebarwienia i prawdopodobnie bardzo drobne $(<1 \mu \mathrm{m})$ produkty utlenienia, zlokalizowane w miejscach koncentracji naprężeń. W mikroskali można jednak zauważyć, że oddziaływanie próbki płynu zawierającego dodatki organiczne jest mniej intensywne w porównaniu z płynem zawierającym dodatki nieorganiczne.

Korozja miedzi może wystąpić w określonych, niekorzystnych warunkach i zazwyczaj objawia się w postaci zmian powierzchniowych. Wżery korozyjne powstają pod wpływem kilku niekorzystnych czynników, występujących jednocześnie i są skutkiem zakłóceń tworzenia się warstwy ochronnej. W procesie tworzenia wżerów korozyjnych w miedzi kluczowe znaczenie ma odczyn wody. Wysokie $\mathrm{pH}$, o wartości powyżej 8, które występuje w wielu płynach niskokrzepnących, sprzyja tworzeniu wżerów korozyjnych. 
Aluminium charakteryzuje się niższym potencjałem elektrochemicznym niż większość typowych metali konstrukcyjnych, zatem ryzyko jego narażenia na korozję elektrochemiczną jest większe w obecności np. miedzi czy stali. Powierzchnia płytek aluminiowych badanych w płynie zawierającym pakiet dodatków nieorganicznych została pokryta ciemnym osadem, widocznym w makroskali. W przypadku tych płytek zaobserwowano największy średni przyrost masy, jednak masa płytek po badaniu nie przekraczała górnej granicy przyjętego kryterium akceptacji.

W ocenie makroskopowej nie stwierdzono zmian korozyjnych w wyniku działania płynu, zawierającego dodatki nieorganiczne. W skali mikro zaobserwowano, że oddziaływanie płynu zawierającego dodatki nieorganiczne skutkowało powstawaniem nieciągłych, przezroczystych warstw na powierzchni płytek aluminiowych.

W wyniku procesów elektrochemicznych zachodzących w ogniwie z wbudowaną elektrodą aluminiową, w roztworze mogły pojawiać się jony glinu, które mają zdolność tworzenia związków kompleksowych w środowisku wodnym. Inhibitorami korozji typu nieorganicznego w płynach niskokrzepnących są przeważnie krzemiany i azotany. Charakterystyczną cechą krzemianów jest zdolność tworzenia glinokrzemianów. Odbywa się to poprzez koordynowanie atomów glinu przez centralny atom krzemu, który w sieci krystalicznej jest połączony silnymi wiązaniami typu sigma z czterema atomami tlenu, tworząc konfigurację tetraedru. Zarówno związki kompleksowe jak glinokrzemiany charakteryzuje zdolność tworzenia trwałych powłok o znacznej odporności.

Powierzchnia płytek aluminiowych oddziałujących z płynem zawierającym inhibitory korozji typu organicznego nie została pokryta warstwą wyraźnie widoczną w makroskali. W mikroskali zaobserwowano jednak, że oddziaływanie próbki zawierającej dodatki organiczne skutkowało obecnością na powierzchni płytki aluminiowej drobnej frakcji cząstek o charakterze krystalicznym. Ośrodki krystaliczne formujące się na powierzchni metalu mogą zaburzać jego uporządkowaną strukturę i prowadzić do intensyfikacji procesów elektrochemicznych zachodzących w miejscu ich występowania i tym samym zwiększać ryzyko wystąpienia korozji.

Znormalizowane metody badań pozwalają skutecznie kontrolować jakość płynów niskokrzepnących dedykowanych do ICECS. Złożony skład płynów niskokrzepnących jest komponowany w taki sposób, aby była zapewniona właściwa ochrona metali konstrukcyjnych w pojazdach i urządzeniach, których prognozowany czas eksploatacji jest o wiele krótszy niż czas użytkowania infrastrukturalnych wymienników ciepła w przemyśle i budownictwie. Wykorzystane w badaniu techniki mikroskopowe pozwoliły dostrzec różnorodne zmiany na powierzchniach metali, które mogą stanowić cenne informacje dla inwestorów na etapie projektowania instalacji i wyboru odpowiedniego czynnika roboczego do napełniania infrastrukturalnych systemów HVAC. 


\section{Literatura}

1. https:// alpari.net.pl/blog-motoryzacyjny/item/12-plyn-chlodzacy, dostęp 05.06.2019.

2. https://www.auto-swiat.pl/porady/eksploatacja/jak-dobrac-odpowiedni-plynchlodniczy/ serrpsh, strona dostępna 05.06.2019.

3. https://www.valvoline.com/our-products/antifreeze-products/antifreezeeducation/engine-coolant, strona dostępna 26.11.2019.

4. Łobodziński M.: Płyny chłodnicze - skład, rodzaje i eksploatacja: https://autokult.pl/2217,plyny-do-chlodnic-samochodowych-sklad-rodzaje-ieksploatacja, strona dostępna 26.11.2019.

5. Norma PN/C-40007:2000 - Płyny niskokrzepnące do układów chłodzenia silników spalinowych - Wymagania i badania.

6. Norma PN-C-40008/07 + PN-C-40008/07/Az1:2000 Płyny niskokrzepnące do układów chłodzenia silników spalinowych - Badanie właściwości korozyjnych w naczyniu szklanym.

7. Tang Z.: A review of corrosion inhibitors for rust preventative fluids. Current Opinion and Solid State \& Materials Science, Vol. 23, 2019.

8. Wojciechowski J.: Rola związków krzemoorganicznych w ochronie metali oraz stali przed korozją elektrochemiczną. Politechnika Poznańska, Wydział Technologii Chemicznej, rozprawa doktorska, Poznań 2019. 